\title{
Consideration of Future Consequences dan Kecanduan Internet pada Mahasiswa
}

\author{
Hijir Yoesryna Meutia ${ }^{(1)}$, Arum Sulistyani ${ }^{(1)}$ \\ ${ }^{(1)}$ Fakultas Kedokteran Program Studi Psikologi Universitas Syiah Kuala, Banda Aceh, Indonesia
}

\begin{abstract}
The internet is a medium to easily and quickly access various information. In addition to this positive impact, the internet also causes a negative impact, such as addiction. Consideration of future consequences is one factor that affects internet addiction. The purpose of this study was to examine the relationship between consideration of future consequences and internet addiction among students from Syiah Kuala University. This research used a quantitative method with an incidental sampling technique. The overall sample of the study was 220 students consisting of 118 men and 102 women. The data were analysed using Product-Moment Pearson. The results revealed that there was a negative relationship between the consideration of future consequences and internet addiction, indicating how the higher the consideration of future consequences (CFC) the lower the internet addiction, or vice versa, the lower the consideration of future consequences (CFC) the higher the internet addiction among students of Syiah Kuala University.
\end{abstract}

\section{Keywords: consideration of future consequences, university students, internet addiction}

Internet merupakan media untuk memperoleh atau mengakses berbagai informasi dengan mudah dan cepat. Selain berdampak positif, internet juga menimbulkan dampak negatif, seperti kecanduan. Consideration of future consequences (pertimbangan terhadap konsekuensi masa depan) merupakan salah satu faktor yang mempengaruhi kecanduan internet. Tujuan dari penelitian ini adalah untuk menguji hubungan antara consideration of future consequences dengan kecanduan internet pada mahasiswa Universitas Syiah Kuala. Penelitian ini menggunakan metode kuantitatif dengan teknik sampling insidental. Keselurahan sampel penelitian adalah 220 mahasiswa yang terdiri 118 laki-laki dan 102 perempuan. Data penelitian dianalisis menggunakan Pearson Product Moment Correlation. Hasil penelitian menunjukkan bahwa terdapat hubungan negatif antara consideration of future consequences dengan kecanduan internet. Artinya, semakin tinggi consideration of future qonsequences (CFC) maka semakin rendah kecanduan internet, ataupun sebaliknya, semakin rendah consideration of future qonsequences (CFC) maka semakin tinggi kecanduan internet pada mahasiswa Universitas Syiah Kuala.

Kata kunci: consideration of future consequences, mahasiswa, kecanduan internet

MEDIAPSI, 2019, Vol. 5(2), 64-73, DOI: https://doi.org/10.21776/ub.mps.2019.005.02.1

Received: 2019-01-25. Revised: 2019-09-09. Accepted: 2019-11-05. Published online: 2019-12-05

Handling Editor: Intan Rahmawati, Universitas Brawijaya, Malang, Indonesia

*Corresponding author: Hijir Yoesryna Meutia, Fakultas Kedokteran Program Studi Psikologi Universitas Syiah Kuala,

Banda Aceh, Indonesia. E-mail: hijirym@gmail.com

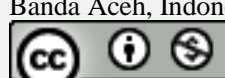

This work is licensed under a Creative Commons Attribution-NonCommercial 4.0 International License.

How to cite this article in accordance with the American Psychological Association (APA) $6^{\text {th }}$ guidelines:

Meutia, H. Y., \& Sulistyani, A. (2019). Consideration of future consequences dan kecanduan internet pada mahasiswa.

MEDIAPSI, 5(2), 64-73. DOI: https://doi.org/10.21776/ub.mps.2019.005.02.1

\section{Pendahuluan}

Dunia teknologi dan informasi saat ini berkembang dengan pesat, yang membawakan kemajuan yang dapat mempermudah kehidupan individu. Salah satu perkembangan teknologi yang telah dikenal sejak lama adalah teknologi internet, yang telah menjadi sebuah kebutuhan banyak orang. Perkembangan teknologi informasi di zaman globalisasi telah menjadi sesuatu yang lazim sebagai akibat 
dari terjadinya revolusi interaksi sosial. Revolusi interaksi sosial ini terlihat dari kontak sosial yang tidak hanya dilakukan dengan kontak langsung, tetapi juga dapat dilakukan melalui jarak jauh menggunakan media komunikasi seperti internet (Ekasari \& Dharmawan, 2012).

Internet merupakan media untuk mengakses dan mendapatkan berbagai macam informasi dengan mudah dan juga cepat (Anggraeni, Husain \& Arifin 2014). Menurut International Telecomunications Union (ITU), tercatat hingga akhir tahun 2014 jumlah pengguna internet di seluruh dunia mencapai 3 miliar. Sebanyak dua pertiga dari jumlah pengguna internet tersebut berasal dari penduduk di negara-negara berkembang termasuk salah satunya di Indonesia (Yusuf, 2014). Hal tersebut sesuai dengan data statistik dari Kementerian Komunikasi dan Informatika (Kemkominfo). Data in menyatakan bahwa jumlah pengguna internet di Indonesia tahun 2012 berdasarkan survei yang dilakukan Asosiasi Penyelenggara Jasa Internet Indonesia, yang untuk selanjutnya disingkat dengan APJII, mencapai $24.23 \%$ atau 63 juta orang dari total penduduk Indonesia. Selanjutnya pada tahun 2013, jumlah tersebut mencapai 71.19 juta, dan sampai dengan tahun 2014 telah mencapai angka 82 juta orang (Asosiasi Penyelenggara Jasa Internet Indonesia, 2015). Kondisi ini menjadikan Indonesia berada pada peringkat ke delapan untuk kategori pengguna internet di dunia. Jumlah pengguna internet di Indonesia terus mengalami peningkatan dibandingkan tahun sebelumnya (Kemkominfo, 2014).

Besarnya jumlah pengguna internet di Aceh pada tahun 2012 mencapai angka $0.13 \%$ atau 88000 orang (APJII: Asosiasi Penyelenggara Jasa Internet Indonesia, 2012). Hasil survei APJII tahun 2016 menyatakan bahwa mahasiswa adalah pengguna internet paling banyak, yang mencapai angka $89.7 \%$ dibandingkan dengan pelajar $69.8 \%$, pekerja $58.4 \%$, ibu rumah tangga $25.3 \%$ dan lainnya (Asosiasi Penyelenggara Jasa Internet
Indonesia, 2016). Berdasarkan survei sederhana yang dilakukan oleh Dewiratri, Karini, dan Machmuroch (2014), internet tidak dapat dipisahkan dari kehidupan mahasiswa saat ini. Mahasiswa sangat bergantung pada internet, dan ketergantungan ini terkait mulai dengan pengerjaan tugas hingga sekedar pencarian hiburan.

Berdasarkan pemaparan tentang survei sederhana diatas diketahui bahwa mahasiswa merupakan salah satu pengguna aktif internet. Selain itu penelitian lainnya yang dilakukan oleh Ciscosystem bertujuan untuk mengetahui bagaimana ketergantungan manusia dengan internet. Hasilnya menunjukkan bahwa bagi mahasiswa, internet adalah kebutuhan, sekitar separuh (49\% mahasiswa dan $47 \%$ pekerja) mempercayai bahwa penggunaan internet merupakan hal yang sangat penting (Dewiratri dkk., 2014). Ceyhan dan Gurcan (2007) juga mengatakan bahwa individu yang paling banyak menggunakan internet adalah mereka yang berada dalam rentang usia dewasa awal khususnya mahasiswa.

Internet memiliki dampak positif berupa cara baru yang mempermudah dalam pendistribusian berbagai informasi. Kemudahan komunikasi dapat memberikan berbagai ilmu pengetahuan dan menjadikan internet sebagai sebuah kebutuhan gaya hidup bagi masyarakat (Nurmandia, Wigati \& Masluchah, 2013). Dampak negatif dari internet bermula dari bahaya internet yang ternyata dapat menimbulkan bahaya kecanduan bagi penggunanya. Kecanduan internet mirip seperti kecanduan obat-obatan, alkohol, dan judi, yang bersifat patologis. Akibatnya, kecanduan internet dapat mengakibatkan berbagai dampak lain seperti penurunan kinerja, perselisihan dalam perkawinan, perceraian dan kegagalan akademis (Ningtyas, 2012). Penelitian yang dilakukan oleh Putri (2013) kepada 69 mahasiswa di Universitas Surabaya menunjukan beberapa dampak positif dan dampak negatif dari internet. Dampak positif tersebut berupa penggunaan internet untuk 
mengakses hiburan (3\%), bisnis (4\%), memudahkan tugas kuliah atau pekerjaan (10\%), sosialisasi dan komunikasi (30\%), mencari informasi (52\%). Adapun dampak negatif mengakses situs porno $(1 \%)$, menjadi boros (4\%), berdampak fisik seperti mata lelah, pusing, mengantuk dan lain-lain (7\%), menjadi addicted (17\%), acuh terhadap linkungan sosial (26\%) dan menjadi lupa waktu sehingga tugas kuliah tidak dikerjakan (44\%).

Menurut Young (2004), dampak yang dihasilkan dari penggunaan internet yang berlebihan antara lain kehilangan pekerjaan atau kesempatan dalam meraih karir serta pendidikan yang lebih baik, kehilangan kesempatan untuk menjalin relasi dengan lingkungan sekitar, kurang menjalin hubungan yang baik dengan keluarga, dan sebagai media untuk menghindari masalah. Berbagai macam permasalahan yang didapatkan pengguna internet berkaitan dengan penggunaan yang berlebihan, yang menyebabkan kecanduan. Kecanduan di dalam bahasa Indonesia menunjukkan suatu keadaan seseorang yang mengalami ketergantungan (Soetjipto, 2005). Kecanduan internet adalah gangguan kontrol impuls yang bukan disebabkan oleh minuman keras atau intoxicant (Young, 1998).

Mahasiswa juga menggunakan internet untuk mencapai kesenangan dan untuk menghindari perasaan tidak menyenangkan akibat tuntutan tugas dalam perkuliahan (Zulaicha \& Sugiasih, 2011). Perilaku yang cenderung hanya memikirkan kesenangan sesaat dan perilaku menghindar dari pengalaman yang tidak menyenangkan dapat diartikan bahwa individu hanya memikirkan konsekuensi yang akan diterimanya. Konsep dalam psikologi yang membahas tentang pertimbangan sebuah konsekuensi pada perilaku saat ini yang berdampak pada masa depan disebut Consideration of Future Consequences (CFC). Strathman, Gleicher, Boninger, dan Edwards (1994) menjelaskan bahwa CFC menunjukkan sejauh mana orang menganggap perilaku saat ini dapat memengaruhi konsekuensi masa depan baik secara fisik, psikologis maupun sosial. Perilaku sehat maupun tidak sehat yang dipilih oleh individu untuk dilakukannya di dalam keseharian dapat dipengaruhi oleh Consideration of Future Consequences.

Salah satu bentuk perilaku yang tidak sehat ini adalah perilaku kecanduan internet. Young (1998) menjelaskan bahwa kecanduan internet menjadi masalah ketika hal itu sudah mengganggu bagian lain dari kehidupan seperti pola tidur, pekerjaan dan juga interaksi sosial di masyarakat. Suller (2004) juga menambahkan bahwa individu yang sudah kecanduan internet atau dunia online cenderung memisahkan diri dari kehidupan nyata. Penelitian sebelumnya yang dilakukan oleh Joireman, Strathman, dan Balliet (2006) menjelaskan bahwa individu yang kecanduan alkohol dan merokok memiliki CFC yang lebih rendah dibandingkan dengan mereka yang tidak mengonsumsi alkohol dan merokok. Penelitian tersebut juga menemukan bahwa individu yang merokok dan mengkonsumsi alkohol memiliki pemahaman dan pengetahuan yang baik mengenai dampak serta resiko yang diperoleh dari perilaku kecanduan tersebut.

Joireman dkk. (2006) menyatakan bahwa setiap individu dewasa memiliki perbedaan dalam mempertimbangkan masa depan. Lebih lanjut Joireman dkk. (2006) mengemukakan bahwa pandangan individu pada masa depannya sangat dipengaruhi oleh pemahaman, yang secara kognitif berkaitan dengan pola pikir dan secara afektif berkaitan dengan emosi dan pengaruh faktor motivasional dalam hal membuat keputusan. Pengaruh neuropsikologis juga terkait dengan keputusan individu dalam mempertimbangkan masa depannya. Neuropsikologi merupakan salah satu faktor yang memengaruhi CFC yang berhubungan dengan pengaruh struktur dan fungsi otak terhadap proses kognitif yang dapat dilihat melalui perilaku (Joireman dkk., 2006).

Individu yang sudah mengalami kecanduan internet sulit untuk melepas atau 
menghindari perilaku kecanduan internet karena proses kontrol yang dimediasi oleh korteks prefrontal dimana rangsangan dalam otak memiliki hubungan langsung dengan pengambilan keputusan untuk berperilaku seperti kecanduan internet (Brand, Young, \& Laier, 2014). Berdasarkan beberapa uraian di atas, maka penelitian ini dilakukan dengan tujuan untuk mengetahui hubungan antara consideration of future consequences dengan kecanduan internet pada mahasiswa Universitas Syiah Kuala Aceh.

\section{Desain penelitian}

Penelitian ini didesain sebagai penelitian kuantitatif korelasional. Penelitian korelasional adalah penelitian yang dilakukan dengan tujuan untuk mengetahui hubungan dan tingkat hubungan antara dua variabel atau lebih tanpa ada upaya untuk memengaruhi variabel tersebut sehingga tidak terdapat manipulasi variabel (Sugiyono, 2013).

\section{Partisipan}

Populasi pada penelitian ini adalah seluruh mahasiswa Universitas Syiah Kuala di Banda Aceh. Adapun sampel dalam penelitian ini adalah sebagian mahasiswa Universitas Syiah Kuala yang telah memenuhi beberapa kriteria sebagai berikut: 1. Mahasiswa Aktif di Universitas Syiah Kuala; 2. Berusia 18 - 25 tahun; 3. Menggunakan internet lebih dari 5 jam perhari; 4. Menyatakan bersedia menjadi responden dalam penelitian ini. Teknik pengambilan sampel dalam penelitian ini menggunakan metode non probability sampling dengan teknik insidental. Jumlah responden yang terlibat dalam penelitian ini adalah sebanyak 220 mahasiswa terdiri dari 118 lakilaki dan 102 perempuan. Skala disebarkan kepada mahasiswa yang kuliah di Universitas Syiah Kuala. Dari 300 skala yang disebar, terdapat 270 skala yang kembali pada peneliti. Dari 270 jumlah skala yang kembali tersebut, terdapat 50 skala yang tidak memenuhi kriteria, sehingga jumlah skala yang dapat digunakan untuk analisis lanjutan adalah sebanyak 220 skala.

\section{Instrumen penelitian}

Consideration of Future Consequences (CFC). Peneliti menggunakan skala CFC yang dikembangkan oleh Joireman, Shaffer, Balliet, dan Strathman (2012). Pernyataan yang terdapat pada skala terdiri dari dua dimensi yaitu immediate (CFC-I) dan future (CFC-F). Koefisien reliabilitas (alpha cronbach; $\alpha$ ) variabel CFC secara keseluruhan adalah sebesar 0.859, sementara reliabilitas dimensi CFC-I adalah 0.833 dan CFC-F 0.916. Setelah melihat indeks daya beda butir pernyataan yang ditetapkan yaitu $\geq 0.30$, tidak terdapat butir pertanyaan yang gugur. Berdasarkan kedua nilai koefisien reliabilitas, dapat disimpulkan bahwa reliabilitas skala CFC tergolong reliabel. Skala CFC terdiri dari 14 item dengan tujuh alternatif jawaban, yang bervariasi dari 1 (sangat tidak mencerminkan diri responden) sampai dengan 7 (sangat mencerminkan diri responden).

Internet Addiction Test (IAT). Tes kecanduan Internet disusun oleh Young (1998) terdiri dari 20 pertanyaan. Kemudian Widyanto dan McMurran (2004) melakukan analisa psikometri terhadap tes tersebut yang menghasilkan enam faktor kecanduan internet yaitu: ciri khas (salience), penggunaan yang berlebihan (excessive use), pengabaian pekerjaan (neglect work), antisipasi (anticipation), kekurangan kontrol (lack of control), dan pengabaian kehidupan sosial (neglect social life). Analisa secara psikometri tersebut menghasilkan reliabilitas sebesar 0.82 dan alat ukur ini dapat dikatakan cukup reliabel dan valid. Koefisien reliabilitas variabel penelitian menunjukkan nilai alpha cronbach (a) sebesar 0.915. Berdasarkan kedua nilai koefisien reliabilitas pada saat penelitian, maka reliabilitas Tes Kecanduan Internet tergolong reliabel.

Data dalam penelitian dikumpulkan dengan menggunakan dua skala adaptasi. Petrtama adalah Skala Consideration of Future 
Consequences dan kedua adalah Internet Addiction Test. Consideration of Future Consequences diadaptasi dari Joireman dkk (2012) dengan jumlah 14 aitem pernyataan, sementara nternet Addiction Test diadaptasi dari Young (1998) yang terdiri dari 20 pertanyaan dan selanjutnya dilakukan proses expert review.

Proses expert review instrumen alat ukur penelitian dilakukan pada tanggal 20 Februari 2017. Proses expert review dilakukan dengan tujuan untuk melihat ketepatan pernyataan dan pertanyaan yang dikembangkan dalam skala sehingga sesuai dengan variabel atau konstruk psikologis yang diukur. Selain itu para reviewer juga melihat apakah adaptasi skala sudah menggunakan bahasa yang baik dan benar sesuai dengan norma maupun budaya tempat penelitian. Setelah dilakukan expert review alat ukur diterjemahkan kembali dalam Bahasa Inggris (back translation) dan kembali direview untuk memastikan kesesuaian dengan versi aslinya

\section{Hasil}

Teknik analisis data yang digunakan pada penelitian ini adalah teknik Pearson Product Moment Correlation. Metode ini digunakan untuk menganalisis korelasi antara CFC dengan kecanduan internet pada mahasiswa Universitas Syiah Kuala di Banda Aceh yang diperoleh dengan menggunakan bantuan program Statistical Package for Science (SPPS) 22.00 for Windows.

Hasil penelitian menunjukkan bahwa jumlah responden berjenis kelamin laki-laki adalah sebanyak 118 (53.7\%), sementara yang berusia 20 tahun adalah sebanyak 133 (60.5\%). Responden yang bertempat tinggal di kos adalah sebanyak 132 (60\%). Hasil data demografi penelitian menunjukkan bahwa waktu akses internet paling banyak adalah pagi, siang dan malam hari (173 subjek; 78.6\%) dan tempat akses internet yang paling banyak adalah rumah, kampus dan warung kopi (103 subjek; 46.9\%).
Berdasarkan analisis kategorisasi, CFC 32 subjek (14.5\%) berada pada kategori tinggi, 76 subjek (34.6\%) berada pada kategori rendah, dan 112 subjek lainnya $(50.90 \%)$ berada pada kisaran skor atau fluktuasi skor rata-rata sehingga tidak terkategorisasikan tinggi atau rendah. Berdasarkan kategori tingkat kecanduan internet, mahasiswa Universitas Syiah Kuala di Banda Aceh memiliki tingkat kecanduan internet dalam kategori normal sebesar 5\% atau sebanyak 11 mahasiswa, kategori ringan sebesar $11.4 \%$ atau sebanyak 25 mahasiswa, kategori sedang sebesar $56.8 \%$ atau sebanyak 125 mahasiswa, dan kategori berat sebesar 26.8\% atau sebanyak 59 mahasiswa. Artinya mayoritas mahasiswa Universitas Syiah Kuala memiliki tingkat kecanduan internet yang bergerak dari kategori sedang menuju kategori berat.

Hasil uji asumsi menunjukkan bahwa data CFC dan kecanduan internet berdistribusi normal. Hal tersebut dilihat dari hasil uji normalitas variabel CFC yaitu nilai skewness (0.680) dan kurtosis (0.004), dan juga nilai mean dan median sebesar 50.95 dan 51.00. Sementara itu, titik-titik skala CFC mengikuti garis lurus. Adapun variabel kecanduan internet menunjukkan nilai skewness dan kurtosis 1.025 dan 1.003, dengan nilai mean dan median sebesar 66.93 dan 68.00. Titik-titik skala kecanduan internet juga mengikuti garis lurus. Hasil uji asumsi yng lain juga menunjukkan bahwa data pada penelitian ini linear. Hal tersebut dapat dilihat dari hasil uji linearitas yang menunjukkan nilai signifikansi, $p<0.001$.

Hasil uji hipotesis menunjukkan adanya hubungan yang signifikan ke arah negatif antara consideration of future qonsequences (CFC) dengan kecanduan internet pada mahasiswa Universitas Syiah Kuala nilai, $r=-0.777, p<$ 0.001 . Nilai $r^{2}=0.604$, yang artinya bahwa sumbangan efektif consideration of future consequences dalam menjelaskan kecanduan internet adalah sebesar 60.4\%. Hal ini menunjukan bahwa hipotesis diterima, artinya 
terdapat hubungan kea rah negatif antara consideration of future consequences (CFC) dengan kecanduan internet pada mahasiswa Universitas Syiah Kuala. Korelasi negatif tersebut menunjukan bahwa semakin tinggi consideration of future consequences (CFC) maka semakin rendah kecanduan internet pada mahasiswa Universitas Syiah Kuala. Hasil kategorisasi nilai masing-masing skala penelitian menunjukkan bahwa CFC pada mahasiswa Universitas Syiah Kuala berada pada kategori rendah.

\section{Diskusi}

Individu yang memiliki nilai CFC rendah lebih fokus pada kepuasaan sesaat, sehingga individu hanya melakukan sesuatu yang bersifat kepuasan sementara (Appleby dkk., 2005). Hal ini berbanding terbalik dengan individu yang memiliki nilai CFC tinggi yang cenderung memikirkan masa depan, sehingga mereka melakukan hal hal yang bermanfaat di masa depan sebagaimana tercermin dalam perilaku mereka saat ini. Hasil penelitian tersebut juga sejalan dengan penelitian oleh Arnocky, Milfont, dan Nicol (2014) yang menemukan bahwa seorang individu yang memiliki nilai CFC rendah adalah individu yang cenderung tidak peduli dengan konsekuensi perilakunya saat ini dan lebih peduli dengan kepuasaan sesaat.

Selain itu Bushman, Giancola, Parrot, dan Roth (2012) juga menyatakan hal yang sama bahwa individu yang memiliki CFC rendah lebih peduli pada kesenangan sesaat dibandingkan dengan dengan masa depan. Semakin individu berorientasi pada masa kini, individu tersebut semakin cenderung mengambil risiko (Lundberg \& Shapira, 2013). Secara teoritis CFC dinyatakan terdiri dari dua aspek yaitu CFC-Future (CFC-F) dan CFCImmediate (CFC-I). Berdasarkan hasil analisis dalam penelitian ini, skor CFC-I lebih tinggi dibandingkan skor CFC-F. Hal ini sesuai dengan penjelasan McKay, Dempster, dan Mello (2015) dimana individu dengan CFC-I yang tinggi cenderung memfokuskan perhatiannya perhatian pada manfaat secara langsung (immediate consequences) seperti kesenangan dan kehidupan yang hedonis. Individu dengan CFC-F yang tinggi ditandai dengan fokus perhatian dan kesadaran mereka terhadap hal yang akan terjadi dimasa depan (distant future consequences) (McKay, Cole, \& Percy, 2015).

Penelitian Joireman dan King (2016) mengungkapkan bahwa individu yang memilki nilai CFC-F yang tinggi biasanya menjauhi perilaku yang tidak sehat seperti kecanduan alkohol. Joireman dan King (2016) menjelaskan lebih lanjut bahwa concern yang tinggi terhadap konsekuensi masa depan dapat mengurangi keinginan individu untuk berorientasi pada kesenangan yang bersifat temporal seperti merokok dan mengonsumsi alcohol, yang identic dengan kecanduan internet. Seseorang yang memiliki nilai CFC-F tinggi biasanya beruoaya memprediksikan apa yang akan terjadi dimasa depan dibanding dengan seseorang yang memiliki CFC-I tinggi. Selain itu, individu yang memiliki CFC-F cenderung menjalankan pola hidup sehat (Joireman dkk., 2012).

Jumlah mahasiswa yang memiliki kecanduan internet pada kategori sedang dan berat lebih banyak dibandingkan dengan jumlah mahasiswa yang berada pada kategori ringan dan normal dari total sampel penelitian Mahasiswa Universitas Syiah Kuala. Mahasiswa yang termasuk dalam kategori kedua tersebut harus mulai dapat mempertimbangkan dampak internet terhadap kehidupannya, sedangkan mahasiswa yang termasuk dalam kategori pertama berpotensi mengalami masalah kecanduan internet. Secara garis besar kecanduan internet kategori berat berkaitan dengan dorongan yang tidak terkendali dalam menggunakan internet, yang ditandai dengan hilangnya kontrol, keasyikan, dan penggunaan internet yang termus menerus yang berdampak pada perilakunya kedepan (Young, 2004). Pada kategori ini mahasiswa 
harus mengevaluasi dampak dari internet pada kehidupannya dan mengatasi masalah secara langsung yang timbul akibat penggunaan internet (Young, 2013). Ningtyas (2012) juga menemukan bahwa mahasiswa yang kecanduan internet cenderung kurang mampu mengontrol perilaku dalam bermain internet yang berlebihan, mengendalikan emosi serta kurang mampu dalam mengambil keputusan atau suatu tindakan yang cukup baik terhadap internet.

Kecanduan internet pada mahasiswa Universitas Syiah Kuala yang berada pada kategori sedang dapat disebabkan oleh beberapa faktor. Faktor-faktor ini mencakup peningkatan teknologi yang memudahkan mahasiswa untuk mengakses internet. Hal ini diperkuat oleh data demografis dari penelitian ini yang menunjukkan bahwa sebagian besar mahasiswa (174 responden) menggunakan komputer, laptop, dan handphone untuk mengakses internet. Fakta tersebut sesuai dengan survei APJII (2016) yang menjelaskan bahwa $9.3 \%$ penduduk Indonesia menggunakan komputer, laptop, dan handphone untuk mengakses internet.

Berdasarkan data dalam penelitian ini, tempat mengakses internet yang paling banyak adalah rumah, kampus dan warung kopi. Temuan ini sesuai dengan survey APJII (2016) yang menjelaskan bahwa bagi masyarakat Indonesia, tempat yang paling sering digunakan untuk mengakses internet adalah rumah $13.3 \%$, kampus $2.2 \%$, warung internet $1.6 \%$, cafe $0.9 \%$. Pada era globalisasi, wireless menjadi salah satu kemudahan individu dalam mengakses internet yang dapat dilakukan dimana saja dan kapan saja. Kemudahan untuk mengakses internet melalui layanan operator internet mobile yang sangat terjangkau membuat pengguna semakin tergantung pada internet itu sendiri. Hal ini sesuai dengan survey APJII (2016) yang menjelaskan bahwa $25.5 \%$ penduduk Indonesia menyatakan bahwa operator internet mobile harganya murah dan $45 \%$ menyatakan bahwa signal internet kuat.
Penelitian ini memiliki sumbangan efektif $r^{2}=0.604$, yang menunjukkan bahwa consideration of future consequences berkontribusi terhadap kecanduan internet sebesar $60.4 \%$, sedangkan prosentase sisasnya dipengaruhi oleh variabel yang lain. Penelitian yang dilakukan oleh Anggraeni dkk. (2014) menyatakan bahwa kecanduan internet juga dapat dipengaruhi oleh tipe kepribadian introvert. Penelitian Kim, LaRose dan Peng (2009) pada mahasiswa di Midwestern menyatakan bahwa kesepian memiliki hubungan yang signifikan dengan kecanduan internet. Young dan Rodger (1998) menyatakan bahwa kecanduan internet dapat dipengaruhi oleh tingkat depresi seseorang. Chak dan Leung (2004) juga melakukan penelitian yang melaporkan bahwa perasaan malu dan locus of control seseorang dapat memengaruhi kecanduan internet. Penelitian Ningtyas (2012) di Universitas Semarang menyebutkan bahwa terdapat hubungan yang signifikan antara kontrol diri dengan kecanduan internet. Penelitian tersebut dijelaskan bahwa faktor yang menyebabkan mahasiswa menghabiskan banyak waktunya untuk menggunakan internet secara berlebihan adalah kurangnya kemampuan dalam mengontrol emosi serta dorongan dalam diri mereka untuk tidak menggunakan internet secara berlebihan, serta kurangnya kemampuan dalam mengambil keputusan atau suatu tindakan yang cukup baik terhadap penggunaan internet.

Berdasarkan uraian tersebut di atas, simpulan yang dapat dipaparkan adalah:

1. Hasil penelitian ini menunjukan bahwa ada hubungan negatif antara consideration of future consequences (CFC) dengan kecanduan internet pada mahasiswa Universitas Syiah Kuala.

2. Hubungan negatif mengindikasikan bahwa semakin tinggi CFC maka semakin rendah kecanduan internet pada mahasiswa Universitas Syiah Kuala dan sebaliknya.

3. Sumbangan efektif CFC terhadap 
kecanduan internet sebesar $60.4 \%$ sementara $39.6 \%$ dipengaruhi oleh faktor-faktor lain yang tidak diteliti dalam penelitian ini.

Saran yang bisa diberikan untuk beberapa pihak adalah, pertama, bagi mahasiswa yang sedang kecanduan internet diharapkan agar menjadi semakin bijak, waspada, dan selektif dalam memilih kegiatan dalam mengakses internet dan dapat mengontrol kegiatannya agar tidak merugikan diri sendiri. Selain itu, diharapkan mahasiswa dapat meningkatkan kesadaran (awareness) dan kekhawatiran akan dampak kecanduan internet dalam kehidupan sehari-hari, seperti salah satunya memikirkan kesehatan dalam jangka pendek dan jangka panjang.

Kedua, kepada peneliti selanjutnya yang tertarik untuk meneliti CFC dan kecanduan internet pada mahasiswa Universitas Syiah Kuala untuk dapat mempertimbangkan variabel lain yang mungkin dapat mempengaruhi kecanduan internet seperti tipe kepribadian, tingkat depresi, locus of control, kesepian dan perasaan malu.

\section{Daftar Pustaka}

Anggraeni, M., Husain, A. N., \& Arifin, S. (2014). Hubungan tipe kepribadian introvert dengan kecanduan internet pada siswa kelas X di SMAN 1 Banjarmasin. Jurnal Berkala Kedokteran, 10(1), 1-8. http://dx.doi.org/10.20527/jbk.v10i1.392

Appleby, P. R., Marks, G., Ayala, A., Miller, L. C., Murphy, S., \& Mansergh, G. (2005). Consideration of future consequences and unprotected anal intercourse among men who have sex with men. Journal of Homosexuallity, 5(1), 119-133. https://doi.org/10.1300/J082v50n01_06

Arnocky, S. Milfont, T. L., \& Nicol, J. R. (2014). Time perspective substainable behavior: Evidence for the distinction between consideration of future consequences. Environment and Behavior, 46(5), 556-582.
https://doi.org/10.1177\%2F00139165124 74987

Asosiasi Penyelenggara Jasa Internet Indonesia. (2012). Profil pengguna internet Indonesia 2012. Diakses pada tanggal 29 November 2015 dari https://www.scribd.com/doc/311659748/P rofil-Internet-Indonesia-2012-

INDONESIA-pdf

Asosiasi Penyelenggara Jasa Internet Indonesia. (2015). Profil pengguna internet Indonesia 2015. Diakses pada tanggal 7 desember $2016 \quad$ dari http://www.apjii.or.id/read/content/Statist $\mathrm{ik} / 305 . \mathrm{html}$

Asosiasi Penyelenggara Jasa Internet Indonesia. (2016). Profil pengguna internet Indonesia 2014. Diakses pada tanggal 11 november $2015 \quad$ dari http://www.apjii.or.id/read/content/Statist $\mathrm{ik} / 305 . \mathrm{html}$

Brand, M., Young, K. S., \& Laier, C. (2014). Prefrontal control and Internet addiction: A theoretical model and review of neuropsychological and neuroimaging findings. Frontiers in Human Neuroscience, 8(375), 1-13. https://doi.org/10.3389/fnhum.2014.0037 5

Bushman, B. J., Giancola, P. R., Parrot, D, J., \& Roth, R, M. (2012). Failure to consider future consequences increases the effect of alcohol on agression. Journal of Experimental Social Psychology, 48, 591595. doi: 10.1016/j.jesp.2011.11.013

Ceyhan, E. \& Gurcan, A. (2007). The Validity and reability of the problematic internet usage scale. Educational Science: Theory \& Pratice, 7(1), 411-416. Diakses dari https://pdfs.semanticscholar.org/db6f/071 f1908ba517dec0293287543036aa7bea2.p df

Chak, K., \& Leung, L. (2004). Shyness and locus of control as predictors of internet addicition and internet use. 
Cyberpsychology \& Behavior, 7(5), 559570. DOI: 10.1089/cpb.2004.7.559

Dewiratri, T., Karini, S. M., \& Machmuroch. (2014) Hubungan antara kecanduan internet dan depresi pada mahasiswa pengguna warnet di Kelurahan Jebres Surakarta. Jurnal Ilmiah Psikologi Candrajiwa, 3(2), 76-84.

Ekasari, P., \& Dharmawan, A. H. (2012). Dampak sosial-ekonomi masuknya pengaruh internet dalam kehidupan remaja di pedesaan. Jurnal Sosiologi Pedesaan, 6(1), 57-71. Diakses dari https://jai.ipb.ac.id/index.php/sodality/arti cle/download/5809/4483

Joireman, J., \& King, S. (2016). Individual differences in the consideration of future and (more) immediate consequences: A review and directions for future research. Social and Personality Psychology Compass, 10(5), 313-326. https://doi.org/10.1111/spc3.12252

Joireman, J., Shaffer, M. J., Balliet, D., \& Strathman, A. (2012). Promotion orientation explains why future-oriented people exercise and eat healthy: Evidence from the two-factor consideration of future consequences-14 scale. Personality and Social Psychology Bulletin, 38(10), 1272-1287.

https://doi.org/10.1177\%2F01461672124 49362

Joireman, J., Strathman, A., \& Balliet, D. (2006). Considering future consequences: An integrative model. In L. Sanna \& E. Chang (Eds.), Judgments over time: The interplay of thoughts, feelings, and behaviors (pp. 82-99). Oxford: Oxford University Press.

Kementerian Komunikasi dan Informasi (2014). Pengguna internet di Indonesia capai 82 juta. Kominfo.go.id Diakses dari https://kominfo.go.id/index.php/content/d etail/3980/Kemkominfo\%3A+Pengguna+ Internet+di+Indonesia+Capai+82+Juta/0/ berita_satker\#.VTB5HNKUeoc
Kim, J., LaRose, R., \& Peng, W. (2009). Loneliness as the cause and the effect of problematic internet use: The relationship between internet use and psychological well-being. Cyberpsychology \& Behavior, 12(4), 451-455. DOI: 10.1089/cpb.2008.0327

Lundberg, M., \& Shapira, G. (2013) Determinants of risky behavior. In Damien de Walque (Ed.), Risking your health: Causes, consequences and intervention to prevent risky behavior ( $\mathrm{pp}$. 37-60). Washington DC: The World Bank.

McKay, M. T., Cole, J. C., \& Percy, A. (2015). Further evidence for a bifactor solution for the consideration of future consequences scale: Measurement and conceptual implications. Personality and Individual Differences, 83, 219-222. https://doi.org/10.1016/j.paid.2015.04.022 McKay, M. T., Dempster, M., \& Mello, Z. (2015). Does consideration of future consequences moderate the relationship between aggression and alcohol use in adolescents? Results from the United Kingdom. Addiction Research \& Theory, 23(5), 372-379. https://doi.org/10.3109/16066359.2015.10 09830

Ningtyas, S. D. Y. (2012). Hubungan self control dengan internet addicition pada mahasiswa. Journal of Social and Industrial Psychology, 1(1), 28-33. Diakses dari https://journal.unnes.ac.id/sju/index.php/s ip/article/view/2691/2479

Nurmandia, H., Wigati, D., \& Masluchah, L. (2013). Hubungan antara kemampuan sosialisasi dengan kecanduan jejaring sosial. Jurnal Penelitian Psikologi, 04 (2), 107-119. Diakses dari https://studylibid.com/doc/42801/hubung an-antara-kemampuan-sosialisasi-dengankecanduan 
Putri, N. A. (2013). Subjective well being mahasiswa yang menggunakan internet secara berlebihan. Calyptra: Jurnal Ilmiah Mahasiswa Universitas Surabaya, 2(1), 1-16. Diakses dari http://journal.ubaya.ac.id/index.php/jimus /article/view/395/261

Soetjipto, H. P. (2005). Pengujian validitas konstruk kriteria kecanduan internet. Jurnal Psikologi, 32(2), 74-79. DOI: 10.22146/jpsi.7072

Strathman, A., Gleicher, F., Boninger, D. S., \& Edwards, C. S. (1994). The consideration of future consequences: Weighing immediate and distant outcomes of behavior. Journal of Personality and Social Psychology, 66(4), 742-752. https://psycnet.apa.org/doi/10.1037/00223514.66.4.742

Sugiyono. (2013). Metode penelitian kuantitatif, kualitatif dan $r \& d$. Bandung: Alfabeta.

Suller, J. (2004). Computer and cyberspace addiction. International Journal of Applied Psychoanalytic Studies, 1, 359362. https://doi.org/10.1002/aps.90

Widyanto, L., \& McMurran, M. (2004). The psychometric properties of the internet addiction test. Cyberpsychology \& Behavior, 7(4), 443-450. https://doi.org/10.1089/cpb.2004.7.443

Young, K. S. (1996). Internet addiction: The emergence of a new clinical disorder. Cyberpsychology \& Behavior, 1(7), 237244. https://doi.org/10.1089/cpb.1998.1.237

Young, K. S. (1998). Internet addiction: The emergence of a new clinical disorder. Cyberpsychology \& Behavior, 1(3), 237244.

https://doi.org/10.1089/cpb.1998.1.237

Young, K. S. (2004). Internet addiction: A new clinical phenomenon and its consequences. Journal American Behavioral Scientist, 48(4), 402-415.
https://doi.org/10.1177\%2F00027642042 70278

Young, K. S. (2013). Internet addiction test (IAT). Dikases dari http://netaddiction.com/internetaddiction-test/

Young, K. S., \& Rodger, R. C. (1998). The relationship between depression and internet addiction. Cyberpsychology \& Behavior, 1(1), 25-28. https://doi.org/10.1089/cpb.1998.1.25

Yusuf, O. (2014, September 27). Pengguna internet dunia tembus 3 miliar. Tekno.kompas.com. Diakses dari http://tekno.kompas.com/read/2014/11/27 /14430067/Pengguna.Internet.Dun ia.Tembus.3.Miliar

Zulaicha, A. \& Sugiasih, I. (2011). Hubungan kecanduan chatting dengan prokrastinasi akademik. Jurnal Proyeksi, 5(2), 53-62. Diakses dari http://fpsi.unissula.ac.id/images/zulaichai nhastuti.pdf 